\title{
The Limits of Hope in the Ancient World
}

For ancient authors from India to China, Greece to

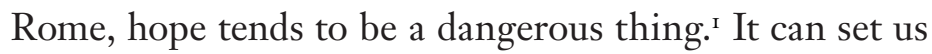
up for practical as well as moral failure. Elpis, the Greek word we translate as hope, is typically an attitude or emotion that is desiderative and goal-oriented, but it can also denote neutral expectation of evils as well as goods. The first author to treat elpis as an unqualified good, given a very specific object of desire (eternal life in Christ), is St. Paul, the earliest writer in the New Testament. Before him, good hopes - including eschatological hopes expressed in other ancient mystery religions - had to be designated as such (agathè elpis, euelpis, hèdious elpides) to be distinguished from bad hopes, which preponderate in Greek literature. ${ }^{2}$ I turn in my next chapter to otherworldly or eschatological hopes, mainly Christian ones; in this chapter, while not drawing too fine a line between the natural and supernatural in ancient thought, I focus on worldly hopes. The classical case against hope has five main points: it is deceptive, blurring our perception of situations and likely outcomes. It compromises our rational agency. It subjects us to its linked opposite, fear. It blinds us to the enjoyment of the present. And most things for which people hope for lack real worth.

What values rise when hope declines? On one hand, hard work, fulfillment of duties, and proper planning based on foresight: I begin this chapter with consideration 
of these values in Hesiod's Works and Days. On the other hand, the awareness of human limits makes humility a key virtue. Overconfidence, unreasonable expectations about what the individual or group can accomplish, link hope to hubris, an ever-present vice of Greek literature. Impudent hope - elpis lacking promatheias (foresight) and aidos (the emotion that limits our self-assertion with regard to others) - is a form of madness (Pindar, Nemean 11, lines 45-48). ${ }^{3}$ But the ancients also recognize good hope, foremost in the competitive strife that defines public life: farm-and-trade productivity, war, athletic games, political activity. Hope could be seen as (and may well be) a necessary motive, linked to confidence and courage.

The ancient world knew also hope in a future ruler, a hope more soteriological than political. This ruler would usher in a new age of justice and peace within and between nations. Such hope flourished in Jerusalem, most famously with the eighth-century вСE prophet Isaiah, and then in Rome, from its fifth-century всE temple to Spes (personified Hope) through to the hopes invested, at least rhetorically, in Octavian, later Augustus Caesar. The Roman "spes race," as one scholar punning calls it, ${ }^{4}$ abides as long as the Western empire does, and may appear more or less continuous with the emphatic hope of Christianity.

Whatever hopes might be expressed for the city-state or empire, the philosophical schools of antiquity developed the case against personal hope and passionate agitation. In the West, Pyrrho's skepticism is the first systematic effort to arrive at freedom from passion or suffering (apatheia) and, positively, undisturbedness (ataraxia). Pyrrho may have been influenced in this aim, as well as in his means of suspended judgment (epochē), by the early Buddhism 
he encountered in India. In Athens, the Epicureans, although hedonists of a sort, aimed as well at ataraxia, in their case through an understanding of the universe as atoms and void. For the Stoics, the passions - including fear, distress, and most forms of hope - constitute false judgments about what kinds of things truly matter. The influence of Stoic philosophy is pronounced in Latin literature as a whole: spes and metus (fear) are commonly paired as complements as well as opposites. ${ }^{5}$ Seneca exemplifies the pairing: "cease to hope ... and you will cease to fear." Nonetheless, Seneca retained hope in patria or the fatherland, and the affective bonds that maintained it.

\section{Hesiod and Aeschylus: Prometheus, Pandora, and the Work of Hope}

Where does hope come from? At what point did we become, by nature, hoping creatures? Greek myth provides two distinct answers. Either hope is a morally ambiguous remnant from Pandora's jar, or it is a gift given by Prometheus. Key texts are Hesiod's late eighthcentury все poem, Works and Days (Erga kai Hèmerai), and Aeschylus's fifth-century все tragedy, Prometheus Bound. In Aeschylus' work, blind hopes are given to mankind directly by Prometheus, his first and only unproblematic gift - his second, fire, is viewed askance by the tragedy's chorus. In Hesiod, elpis arrives not with Prometheus but with Zeus's reprisal against Prometheus' impious gift of fire: that is, the divinely sent Pandora.

The moral status of elpis is an interpretive crux of Hesiod's poem. All we know for sure is that hope has something to do with Pandora, and something to do with 
a container. Pandora's jar (not, as it was sometimes called, a box) is properly a pithos (line 94), ${ }^{6}$ a large vessel. It does not clearly belong to her or arrive with her when the gods send her among men. All Hesiod tells us is that there is a pithos that Pandora opens and that it contains something, and that when Pandora scatters some things (which may be the contents of the jar), ills beset mankind. ${ }^{\text {These }}$ ills, including disease, may be what Pandora scatters, or they may arise from Pandora's dismissal of goods, such as health. Hope alone remains in the pithos, by Zeus's will. The central questions are:

1. Is hope an evil among evil things, or a good among good things?

2. In either case, what does it mean that hope alone, by Zeus's will, is caught or trapped inside the jar? Does it mean that it's made inaccessible to us - think ahead to Kafka, "there is hope, but not for us" - or rather that it's preserved for us? Is Zeus here punishing humans, or showing them mercy?

My sense is that Hesiod treats hope as a potential good, akin to striving, that is preserved for us in the jar by Zeus's mercy. Yet Hesiod also treats hope, later in his poem, as an evil: the empty dreams connected to hubris and improvidence. In seeing hope as the one good that Pandora doesn't lose for us, I concur with E. F. Beall, who argues that what escapes from the jar are all good things except for elpis. When the other goods (such as health and leisure) vanish in the wind, or escape to Mt. Olympus, the evil of their loss besets us. Beall's further argument is that hope as a good, the last good not dispersed, is consistent with the poet Theognis' hymn to 
the goddess Hope as the last beneficent deity left on earth. Theognis writes: "Elpis is the only good deity among human beings: the others have abandoned us and gone to Olympus." 8

In preserving hope for us, Zeus appears to be exercising mercy - though ambiguously so, once we are shown hope's ripeness for misuse. The more fundamental question raised by Hesiod is that of Zeus's justice, if he is just. Hesiod's poem opens, in Richmond Lattimore's translation:

Muses, who from Pieria give glory through singing, come to me, tell of Zeus, your own father, sing his praises, through whose will mortal men are named in speech or remain unspoken.

Men are renowned or remain unsung As great Zeus wills it.

For lightly $[$ reia $]$ he make strong, and lightly $[$ reia $]$ brings strength to confusion, lightly diminishes the great man, uplifts the obscure one ... (I-6)

Breaking Hesiod's hexameter lines into two half-lines on the page, Lattimore brings out both the poet's antithetic parallelism and Zeus's principle of alternation: he makes strong, he brings down. The question is: does justice lie behind these alternations? Does Zeus deal out goods and evils according to just judgment, or through mechanical alternations? Or is Zeus a god who must be urged to justice? Hesiod continues: "Hear me, see me, Zeus: hearken: / direct your decrees in righteousness" (trans. Lattimore) - or, more precisely, "straighten decisions by Dike [justice]." The reader is challenged, Kimberly Johnson observes, to find meaning in the poem's apparent injustices. ${ }^{\text {¡ }}$ 
Works and Days was occasioned by a specific unjust act: Hesiod's brother Perses tried to cheat him in court out of his share of their paternal inheritance. Thus, directly after addressing Zeus, the poet addresses Perses: "To you, Perses, I would describe / the true way of existence" (Iо). Repeatedly in the poem, Perses is urged to work, not to litigate and bribe magistrates, which is strife (eris) of a destructive variety (20-4I, 293-3I9). That magistrates "eat bribes" (39) is due to the ill effects of luxury:

Fools all! who never learned

how much better than the whole the half is nor how much good there is in living on mallow and asphodel.

(trans. Lattimore, 40-4I)

The Loeb edition's note to this last line is misleading: "That is, the poor man's fare, like 'bread and cheese'." Bread and cheese, however, are products of farming and herding labor, while mallow (a wild herb) and asphodel (a barely edible root) are not: they are wild foods, redolent of an earlier state of nature. Having started with a simple exhortation against unjustly seeking the whole when half will do, Hesiod ends up recommending much less than that, with primitive sustenance.

Specifically, Hesiod turns back to the virtue of the uncooked, to food before fire. Without fire, of course, there is no cooked food, no metallurgy, no plough-shares, and no metal swords or spears. Zeus "hid fire," we are told (50) - but why? One answer is to keep men abject. But another and perhaps better answer is to keep them from having to cook and plough, to work and worry, to war over property. In this sense, it is Prometheus, rather 
than Zeus, who is responsible for Pandora. As Patricia Marquardt argues, Pandora is the earth-goddess responsible for the evils that befall the farmer's life, including uncertain weather, drought, crop diseases, and unproduc-

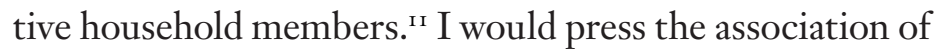
Pandora and farming still further, to suggest that rather than being the scourge imposed by Zeus and the gods, she is, at a deeper level, the natural result of the fire and arts that Prometheus introduced. She arrives on earth, like the plough, that was before her "free from all evils, free from laborious work" (9I); she is designed "to be a sorrow to men/ who eat bread" (82, my emphasis). Not ambrosia, like the gods; not asphodel and mallow, like primitive mortals; but bread, the product of grains and fire.

Seeing Pandora as the presiding goddess of arable earth, Marquardt sees by extension Hesiod's pithos as a metaphor for the earth itself - and hope as that which metaphorically lies in the pithos or earth:

Hope, which Pandora trapped in the pithos "under the rim" [line 97] is not denied to men, as many have interpreted. Hesiod's meaning becomes clear when we think of the pithos as a metaphor for the earth. Man's "hope" of recovering the livelihood (Bios) hidden from him [line 42] rests in the earth despite the toil and misery he must endure to realize it. The paradox is that man's hope for respite from troubles lies in the very earth which makes his tasks necessary and that Pandora, the earth-goddess, who is "responsible" for man's hardship and failure, also provides the sure, although difficult, way out. ${ }^{12}$

Hope is a good thing for the farmer, because it inspires the good strife (eris) of work and emulation (I I-26). Elpis lies behind the motivating "she" (eris) of Hesiod's analysis: 
She pushes the shiftless man to work, for all his laziness.

A man looks to his neighbor, who is rich:

then he too

wants work; for the rich man presses on with

his plowing and planting

and the ordering of his state [oikos]. (20-23)

It is only when divorced from striving, and opposed to it, that elpis becomes for Hesiod a bad thing:

The unworking man, who stays on empty

anticipation [elpida keneèn],

needing substance, arranges in his mind

many bad thoughts,

and that is not a good kind of hopefulness

which is company

for a man who sits, and gossips, and has not enough

to live on.

While it is mid-summer, give your people their orders.

It will not always be summer. The barns

had better be building. (498-503)

In farm life, empty hope - hope that something might come one's way - distracts from the necessity of provident labor. Hesiod here parallels the Aesop Fable, "The Ant and the Grasshopper": a hungry, because improvident, grasshopper (originally, a cicada), who spent the summer singing, not working, begs for food from an ant when winter comes - and is refused. With Hesiod, the tale propounds a moral lesson about the virtue of hard work and providing for a future that nonetheless remains uncertain, subject to fortuna or the principle of alternation. 
But, as a counterpoint to his insistence on work, Hesiod indulges as well in the hopeful fancy that, through the cyclical revolutions of time, a golden age might return that will free us from the regime of hope, work, and strife. In the opening section of Works and Days, lines I-20I, Hesiod tells two consecutive stories about the relation of mortals to the gods. The first, the Pandora story, focuses, as we've seen, on one epochal event: the introduction of fire/Pandora/farming among men. There was ease; there is now work and disease. But Hesiod's second version of the story of the god's relations to men (I09-20I) is centered not on one epochal event but, rather, on historical stages of decline, or as Jeanne Pierre Vernant cogently argues, historical cycles that will lead us, past the iron ages, directly or indirectly back to the golden age. ${ }^{13}$ In this cyclical view of history, bad things are associated not with human laziness feeding on false hope, but rather with bubris flouting justice (dike ). Vernant shows that Hesiod arranges his five (or six) ages - gold, silver, bronze, age of heroes, and iron (itself divisible into two ages) - not according to a pattern of decline, but rather according to relations to justice. In both the gold and silver ages, there is no labor, but the silver age is, unlike the gold, one of hubris, injustice, and impiety. The silver is the worst age. The bronze and heroic ages are defined by physical force, immoderate in the bronze age (when they "ate no bread" [I46]) and moderated in the heroic age of Thebes and Troy (where production lies outside Hesiod's purview). The iron age, in which Hesiod situates himself, is defined by labor and bread, but Vernant has discovered two iron ages (or phases of the age): now there is good mixed with evil; at a later time there will be unadulterated evil. 
Children will be born old; there will be no more marital fidelity, friendship loyalty, or piety toward parents. "Right will be in the arm. / Shame will not be" (193). Once we get to this second iron age, the cycle of the ages will start again, either in original order (starting with the golden) or in reverse order (back through the first iron age, then the age of heroes, and so on).

However, Hesiod intimates that the second iron age might be deferred, or avoided, by human action. The last age might be only a conditional one: if you continue to act unjustly, then such doom shall follow. His whole story about cyclical ages and their seemingly inexorable pattern ends with an exhortation about acting justly: "But as for you, Perses, listen to justice; / do not try to practice violence" (213-I4). Hesiod expresses hope, moral rather than political, that the last stage of history, unmixed evil, might not lie ahead for the just community:

But when men issue straight decisions [dikas]

to their own people

and to strangers, and do not step at all

off the road to rightness,

their city flourishes, and the people

blossom inside it ...

Neither famine nor inward disaster comes the way

of those people

who are just and straight; they do their work

as if work were a holiday;

the earth gives them great livelihood

on their mountains the oaks

bear acorns for them in their crowns,

and bees in their middles.

Their wool-bearing sheep are weighted down with fleecy burdens. 
The women bear them children who resemble their parents.

They prosper in good things throughout.

They have no traffic

with ships, for their own grain-giving land yields them its harvest. (225-37)

Hesiod here offers hope in the just community, where because of dike, the city flourishes and work can seem a holiday. The earth pays its tribute of acorns, bees, and fleeces, and, amidst local abundance, there is no longer "traffic with ships" - neither commerce nor conquest. (The end to ships will prove an enduring part of golden age and Christian-eschatological visions, from Virgil to the Book of Revelation.)

In this dialectical moment of Works and Days, work is imaginatively reconciled with the golden age. We return to native leisure on a higher plane, fed by bread as well as honey and nuts; mallow and asphodel are no longer to our liking. Hesiod's hopeful vision has as its rhetorical purpose an incentive to virtue (if you'd like such a world, then you should act in such a way), much as his contemporary Isaiah's does. But insofar as we imagine Hesiod believing in the possibility of light-hearted labor in a beneficent earth, we move beyond ancient pessimism and into something more progressive - even if his hope is not exactly political.

Prometheus Bound - the first and only fully extant play of Aeschylus' Prometheus-trilogy - opens on the Titan shackled to a rock in the mountains of Scythia. Prometheus in his ghastly punishment doesn't need hope, because he clearly foresees the future and in it his eternal redemption. He believes that mortals, by contrast, 
need something to blind them to their very mortality. He thus gives them "blind hopes" ("tuphlas elpidas," line 252). ${ }^{14}$ Such hopes allow mortals to ignore their inevitable deaths, and live with projects or strivings they might not survive to finish, but that nonetheless may outlast them. This gift is much approved by Aeschylus chorus. Yet the chorus questions the piety and benefit of Prometheus' second gift, fire (254-64), and with it, as he later boasts, metallurgy, agriculture, and all the arts, or technai (442506). The fire that enables civilization appears to the chorus as an offense, one that has brought on, perhaps rightly, Zeus's punishment and promise of further punishment, an eagle that will devour his liver if he does not comply with Zeus's will.

Between Aeschylus and Hesiod, a simplified opposition was once conventional: Hesiod, the pessimist-primitivist, contrasts Aeschylus, the proponent of civilization and progress. ${ }^{15}$ But the contrast is too stark. There is, we have seen, a progressive strain in Hesiod - the belief that human activity might secure some communal good not simply given by the gods - and, conversely, Aeschylus' drama doesn't depict Prometheus' gift of fire as an unqualified good (neither, in turn, will Percy Shelley in Prometheus Unbound). Nonetheless, Aeschylus gives Prometheus a heroic, tragic stature he lacked in earlier Greek literature. ${ }^{\mathrm{I}}{ }^{2}$ Zeus, in turn, becomes a tyrant. Early in the play, personified Strength (Kratos) tells the chained Prometheus, "No one is free butZeus." ${ }^{17}$ We over-simplify, however, if we imagine Zeus as nothing but a despot and Prometheus as nothing but a savior. Aeschylus unfolds the consequences, bad as well as good, of what follows inevitably from fire and civilization. 
Insight into inevitability - or, at least, into conditional necessity - is Prometheus' main power in Aeschylus' tragedy. Aeschylus makes Prometheus Earth's son (and thus a Titan or early god), not her grandson (as he is in Hesiod's Theogony), and puts him in touch with her foreknowledge of necessity or destiny (anagkē). In his first speech, Prometheus only briefly forgets that he knows everything, including the period of his pain:

I groan in anguish

For pain present and pain to come:

Where shall I see rise

The star of my deliverance?

What am I saying? I know exactly every thing

That is to be; no torment will come unforeseen.

My appointed fate I must endure as best I can,

Knowing the power of Necessity is irresistible.

(p. 24 [98-IO4])

What Prometheus knows that his tormentor Zeus does not is the so-called marriage secret. Zeus, if he isn't forewarned in time, will procreate with a female whose son will then be stronger than he is. (Prometheus doesn't identify the identity of this female in this first play in Aeschylus' trilogy, but presumably it is the sea-goddess Thetis, later married off by the gods to a mortal, Peleus.) Prometheus thus knows things that even an Athenian audience might not be entirely sure about, even if familiar with the general outline of what later fragments of the Promethean trilogy reveal to us: Prometheus will avert Zeus's marriage to the fatal female; Zeus will prove gentle in his later dealings with Io, who will then give birth to the hero, Herakles, who 
will unchain Prometheus; Prometheus and Zeus will be reconciled.

In Prometheus Bound, the Titan does two things that are clearly good for mortals: he saves them as a group from Zeus's proposed genocide, and then provides hope to blind them to their deaths. Zeus, upon seizing power from the Titans (with Prometheus' help), decides "of wretched humans" to "annihilate them and create another race," but Prometheus somehow intervenes: "I saved the human race from being ground / To dust, from total death" (p. $27[234-38]) .^{18}$ But Prometheus' third and most elaborate gift - fire and all that it enables - is a more ambiguous good for mortals and reflects back not entirely well on Prometheus and his intentions, which seem less merciful than self-aggrandizing. The chorus that approved blind hopes in the face of death responds with concern or alarm to fire:

PROMETHEUS: I planted firmly in their hearts blind hopefulness.

CHORUS: Your gift brought them great blessing. PROMETHEUS: I did more than that: I gave them fire.

CHORUS: What? Men, whose life is but a day [ephèmeroi], possess already the hot radiance of fire?

PROMETHEUS: They do, and with it they shall master many crafts.

CHORUS: This then was the offence for which you suffer here - (p. 28 [252-57])

Vellacott renders the chorus's judgment in this last line more definitively than it appears in the Greek, but the chorus expresses no doubt a few lines later: "you have done wrong" ("hēmartes," 26r). 
The error or sin seems to lie in giving the power of fire to the ephemeral beings that mortals are. Death is a weakness, and fire may simply be wasted on such weaklings, or the chorus may think it an impiety to extend their brief day, both into night and into futurity. Finally, however, the chorus may intuit that fire enables weak creatures to waste themselves through the arts that Prometheus proudly announces all stem from and belong to him. Prometheus lays claim to making mortals properly human, giving them with fire reason, numeracy, literacy, cattle, ships, medicine, prophecy, augury, and all metals, bronze, iron, silver, and gold (pp. 34-35 [443-506]). He concludes, "all skill and science [technai] given to mortals are from Prometheus" (line 506, my translation). ${ }^{19}$ Prometheus' focus is less on the good of man than on the glory of his gifts. Of teaching navigation, he emphatically asserts, "no other [did it] before me" (467, compare 503).

Yet the Greeks were ambivalent about ships: in Hesiod's just and flourishing community, there is no "traffic in ships." Did Prometheus help mortals, or load them with evils? This latter possibility comes to the fore in a Horatian ode we may read as a gloss on Aeschylus:

Daring all [Audax omnia], their goal to win,

Men tread forbidden ground, and rush on sin:

Daring all, Prometheus play'd

His wily game, and fire to man convey'd;

Soon as fire was stolen away,

Pale Fever's stranger host and wan Decay

Swept o'er earth's polluted face,

And slow Fate [necessitas] quicken'd Death's once halting pace. $^{20}$ 
For Horace, fire directly or indirectly (via Zeus's punishment) causes these ills. One clue that Prometheus and his gift are to blame is that in a subsequent ode (I.I6.15-16), Horace claims that the god put "the force of a mad lion," "insani leonis vim," into the human gullet or stomach (stomachus). This ode would have strengthened Percy Shelley's interpretive case, in his prose work A Vindication of Natural Diet, that Horace in I.3 was specifically denouncing fire for "culinary purposes." For Shelley, and Horace as he reads him, meat-eating is at the root not only of premature death but also "all vice," arising "from the ruin of healthful innocence." What Prometheus gives men, in short, is what Pandora's jar, or her hand, spread in Hesiod: work, disease, shortness of life. Not that these things were ever really absent from mortal life - but, in the nostalgic imagination of sedentary peoples, life before farming - or meat-eating, or fire - could seem, like earliest childhood, a time of innocence and ease. Only blind hope would leave it behind.

\section{Pindar, Thucydides, and the Fragility of Good Hope}

Blind hopes receive unfavorable notice in Pindar's Olympian I2. A victory ode for an athlete resident in Sicilian Himera, Olympian I2 is also a hymn to Tucha, the goddess of chance or fortune. In Frank Nisetich's prose translation:

I beseech you, O Savior Tycha, daughter of Zeus the Deliverer, watch over Himera in her broad strength. Yours is the steering of swift ships on the sea, of rushing wars on land, and of assemblies that bring forth counsels. But the hopes of men 
are pitched and tossed, often up, and then down, as they cut through vain illusions: no one of them on earth has found a trustworthy token from the gods concerning what is about to happen. Our perception of the future has been blinded. ${ }^{22}$

Blinded, in Aeschylus' account, by Prometheus. Tycha, like Zeus, sees ahead and controls; humans, with blind hopes, are buffeted as though by waves on a rough sea, up and down. Elpis, Nisetich notes, "often connotes futility." "With the gods, there is vision and power to fulfill it; with men, there is blind hope without power."23

In contrast to the pessimism of Olympia I2, Pindar elsewhere admits some human freedom and the qualified category of "good hope," "agathan elpida." Turning from danger (the threat of Xerxes' invasion, now removed), Pindar stresses hope's proper limitation to what lies close before us:

... it is better always to watch what is close at hand in everything.

A treacherous age hangs over men's heads;

it makes crooked the way of life. But even this can

be healed

in man, with freedom. We must be of good hope.

(trans. Lattimore, I4-I 7$)^{24}$

This hope, based on lack of foresight, aims at what is feasible and supplies a necessary motive to competitive striving in athletics, war, and poetry. ${ }^{25}$ It is hope for good reputation or glory, a good Pindar acknowledges in Pythia I: "The vaunt of reputation to come / alone attests the life of those who are gone, / in song and story" (93-94).

Good hope appears in certain Pindar odes as a mean or measure between two extremes: overconfidence, on one hand, and excessive caution, on the other. In Pindar's 
victory or epinician odes, hope as a good thing blends into the virtue Aristotle will later analyze, courage (andreia, at Nichomachean Ethics 3.6), the mean between foolhardiness and cowardice. Pindar's most elaborate treatment of good hope comes in Nemean II, which begins with deficient hope. The ode is addressed to Aristagoras, a newly installed magistrate in Tenedos and in the past a victorious athlete - yet, Pindar frets, not as victorious as he had the potential to be had his parents entered him earlier in life into the Panhellenic games:

The hopes too hesitant of his parents kept their son's strength from endeavor in the games at Pytho and Olympia.

By oath, I say, to my thinking had he ventured beside Kastalia and the grove of the slope of Kronos, he had come back in glory beyond his straining antagonists ... (trans. Lattimore, $2 \mathrm{I}-26$ )

Alexandre Johnston observes that "in implicit contrast to the overly hesitant hopes of ... [his parents], the speaker boldly visualizes a brilliant career for Aristogoras" 26 Pindar's imaginative, counterfactual hope supplies the lack found in the athlete's parents - a lack partly due, in the Greek mind, to their advanced age. ${ }^{27}$

But then Pindar suddenly censures the opposite extreme, arrogant confidence - "one man, light-minded, vaunting hopes / drive from the good" - before returning to insufficient hope: "another one ... blames overmuch/ his own strength" (29-3I). In his final stanza, Pindar briefly suggests a dialectical resolution in measured hope, but the forethought (promatheia) upon which it depends may be no more available to us than it was in Olympia I2: 
From Zeus comes no clear sign

to men. Even so we go abroad in our manhood's height, pondering many designs; for our limbs are shackled to shameless hope, and the streams of forethought lie afar.

We should seek out some measure in things gained;

too bitter are the pangs of madness after loves that are past attainment. $(43-48)$

"Shameless hope" aims at what one doesn't deserve and what one will never achieve; it is a mistaking of one's status with respect to gods and other men. Conversely, the hope of someone with forethought and shame or restraint (aidos), Johnston ventures, "may be seen as a limited but possible avenue into an otherwise impenetrable future." She admits, however, that we are not told how to attain, or assured that we can attain, "the streams of forethought." ${ }^{28}$ Thus, even here Pindar's allowance for good hope is overwhelmed by hope's more basic connection to madness and waking dreams. Pindar reflects back on his own counterfactual poetic musings on the victories Aristogoras might have won if his parents were more hopeful. Good hope is at best a difficult target in Pindar, and the excesses of imagination come to seem far more fearful than its deficiencies.

But what if subjugation is at hand, and freedom is not an unreasonable hope? Thucydides, the historian of the fifth-century все wars between Athens and Sparta, narrates a Tuche-controlled tragedy of good hope in the famous "Melian Dialogue" of The Peloponnesian War, Book 5 (paragraphs 84-I I6). The Melians are Spartan colonists who, during Athens' long war with Sparta, have neither maintained strict neutrality between the two sides, as 
they promised to do, nor paid Athens the monetary tribute it demanded. Athenian ships and troops arrive at the island of Melos and send representatives to present the islanders with a choice: submit or be destroyed. The question is one of expediency apart from justice. "Justice," the emissaries declare, "is what is decided when equal forces are opposed, while possibilities are what superiors impose and the weak acquiesce to" (5.89). ${ }^{29}$ We have arrived here at Hesiod's second Iron Age, when "Right will be in the arm," but it was in the fourth century an adage that many cultured Athenians accepted - compare Thrasymachus in Plato's Republic, Book I, and Callicles in the Gorgias. The Melians, however, reject the limited "possibility" offered them and assert their willingness to war against the numerically superior Athenians, trusting in the gods and, not unreasonably, in military support from Sparta. "It is our understanding," the Melian delegates respond, "that warfare sometimes admits of more impartial fortune $[t u c h a]$ than accords with the numerical disparity of two sides. For us, to yield is immediately hopelessness, but in action there is still hope of bearing up" (5.102).

The Athenians reply with a sermon against hope in war. Hope is the prerogative of "the richly endowed," those who have enough to venture without a probable chance of threatening loss. By contrast, there is no hope for small states. The Athenians' response to Melian hope is rendered with acute philological commentary by Joel Alden Schlosser:

In the midst of Thucydides' infamous "Melian Dialogue," hope is characterized as "danger's comforter" [Crawley/Strassler translation ${ }^{30}$. The Athenians tell the Melians: “Hope, danger's comforter, may be indulged in by those who have abundant 
resources, if not without loss at all events without ruin; but its nature is to be extravagant, and those who go so far as to put their all upon the venture see it in its true colours only when they are ruined" (5.IO3). There is a remarkable ambiguity in elpis kindunōi paramuthion, the Greek here translated as "hope, danger's comforter" ... Thus Lattimore (1998) translates this passage as "incitement to danger" (297) while Jowett (I88I) offers "good comforter in the hour of danger." The rest of this passage conveys the multiple meanings of hope in "danger's comforter": hope appears as a comfort and as an indulgence, as potentially dangerous even to the powerful, as a cause of loss, and as by its very nature extravagant such that it inevitably leads to ruin..$^{\text {I }}$

Dangerous even to the powerful, but fatal for those without resources.

In the event, the Athenians are proven correct in the belief that the Melians are wrong to expect either divine or Spartan assistance. The gods, the Athenians insist, teach only "to rule wherever empowered," and the Spartans' virtue does not extend beyond their own city (5.105). But the tragedy of the Melians is, first, that their hope was all but inevitable. As the Athenian Diodotos earlier put it in Thucydides' history, in arguing against the death penalty across the board for the rebellious Mytileneans: "Men take the risk nevertheless, led on by their hopes, and no one has ever yet faced the danger already resigned to failing in the attempt." Diodotos then posits as a law of human nature that hope and desire, elpis and erōs, will animate men of all conditions (3.45). Such hopes, Diodotos thought, do great damage, but it's inevitable damage: ineliminable, they must be managed. Thucydides thus prepares our sympathy for the hopeful Melians. But their 
hopes were not only inevitable, but also not unreasonable. Their odds were arguably better than those of the Greeks against the Persians in the 49 os and 480s BCE - or, looking ahead, the British against the Nazis in 1939-40. Even when abandoned by the Spartans, as the Athenians predicted, it is not as easy to crush the Melians as the Athenians expected. They eventually fall due to two contingencies, or acts of Tucha: Athenian reinforcements arrive, and there seems to be a betrayal from within the Melian camp. It is with terrible calm that the historian speeds toward the destruction of the hopeful Melians:

[T] he Melians once again seized part of the wall [protecting the Athenian camp and provisions] in a different area, since there were few on guard. And afterward, when because of these occurrences more forces arrived from Athens commanded by Philokrates ["friend of strength"] son of Demeas, and they were now under heavy siege, also after a certain amount of treachery in their midst [my emphasis], they surrendered to the Athenians to be dealt with as they wished. They killed all the grown men they captured, enslaved the children and women, and settled the place themselves by sending out five hundred colonists later. (5.II6)

The treachery within Melos, a twist of Tuche, is handled by Thucydides with understatement and mid-sentence surprise. Neither the Melians nor the reader finds in advance a trustworthy token of what is to happen next.

\section{Cyclical Revolution and Ruler Hope}

Thucydides' naturalist and tragic vision of history starkly contrasts Hesiod's mythic conception of history as cyclical and stadial, obeying its own laws or divine law, and 
promising a recurrence, however precarious, of golden origins..$^{32}$ Hesiod supplemented his belief in the mythic cycles of history with a moral hope that something like the golden age will return when the people are "straight and just." Distinct from this proto-political hope - the hope of virtue permeating the community - there is the (not mutually exclusive) hope of the city or empire being transformed by extraordinary means.

In this section, I focus on a hope largely absent from Greek thought, though salient in Hebraic and Roman thinking: the hope in a future, perhaps imminent, earthly ruler who will bring about, through his justice and power, a partial return of the golden age. This ruler-hope, as we may call it, is found in the biblical Book of the Prophet Isaiah, and is well known to Christian audiences through Christological interpretations of Isaiah (beginning with the Gospel of Mark, r:2-4) - in which, however, the coming ruler is no longer a mortal or worldly one. Ruler-hope also features in Virgil's fourth or, to Christian audiences, "messianic" Eclogue, foretelling a state of perfect peace and leisure under the leadership of an unspecified male infant, recently or soon to be born.

Isaiah - or "the first Isaiah," the historical figure responsible for most of the Book of Isaiah's first 39 chapters - is an eighth-century все contemporary of Hesiod's. The settings for his sayings are the courts of four successive kings of Judah during the fraught period 780-692 все. Within this time, the northern kingdom of Israel fell to the Assyrians (722 вСE) and Jerusalem was saved only by surrendering to the invaders (7OI BCE). Isaiah presents the kings with prudential, theistic advice: if the king and people rely on God's protection in international 
affairs, and exhibit good intermural behavior, then good things will happen or may justly be hoped for. If the reverse, then doom will ensue. But in the best-case scenario, a divinely inspired ruler will secure Judah from predation by larger powers (the Melian problem), establishing interstate justice, and thus universal justice of a sort, based on universal recognition of the one God of Israel. "And he [God or his Mount Zion representative] shall judge among the nations, and shall rebuke many people: and they shall beat their swords into plowshares, and their spears into pruninghooks: nation shall not lift up sword against nation, neither shall they learn war any more" (2:4). Correcting the Promethean problem, fire and metallurgy will be used for farming only, not for violence and conquest.

In royal hymns composed for the sons of kings, Isaiah gives ruler hope its best-known formulation. "For unto us a child is born, unto us a son is given: and the government shall be upon his shoulder: and his name shall be called Wonderful Counseller, The mighty God, The everlasting Father, the Prince of Peace. Of the increase of his government and peace there shall be no end" (9:6-7). This future peace is characterized as perfectly Edenic in another royal psalm; here, not only shall there be no war, but no violence whatsoever, and no meat-eating among formerly carnivorous creatures: "The wolf also shall dwell with the lamb, and the leopard shall lie down with the kid; and the calf and the young lion and the fatling together; and a little child shall lead them" (гі:6). This pacification of predatory animals may or may not be taken literally as an anticipation of what Isaiah hopes will really happen in a future, possible, and ideal reign. It 
stands at least as a powerful metaphor for the harmony that he imagines might arise from divine obedience and earthly justice. In Isaiah, prophecies of conditional salvation, directed at kings along with oracles of conditional doom, are rhetorical expressions of hope, incitements to act in certain ways in the present.

Virgil's Eclogue, written around 4 О все, is arch in a way that the Hebrew prophet was not. Universal, inter-species peace may have been a metaphor for Isaiah, but in Virgil it appears more as a topos, the occasion for intertextual engagement and literary-historical self-inscription. It is not clear how seriously we should take Virgil's Eclogue as a statement about anything extra-literary. What the poem seems chiefly about is the poet's self-conscious stylistic ascent from a lowly pastoral to a lofty heroic vein, even if it goes too far to think that Virgil may have been anticipating the epic he would later write: the Aeneid, on the mythic roots of Roman imperium in the Trojan exile Aeneas and his destined but fraught voyage west to Italy. Setting aside the larger picture of the Virgilian career, ${ }^{33}$ the fourth Eclogue commences as a self-declared generic experiment in a theme and style higher than pastoral, the genre he inherited from the Sicilian Theocritus. Sicelides Musae, paulo maiora canamus (line I) - "Sicilian Muses, let us sing a little grander." 34 Virgil's third line elevates the woodland with a chiasmus underscored by the alliteration of canimus (we sing) and consule (consul): Si canimus silvas, sylvae sint consule dignae ("If we sing the woods, the woods must be worthy of a consul").

The consul in question, we're later told, is C. Asnius Pollio, a Mark Antony supporter elected 40 вCE. Pollio had earlier protected Virgil's interests during the 
re-distribution of Italian lands to veterans (the subject of Virgil's first Eclogue). His consulship coincides with the Octavian-Antony pact of Brundisium in October of the year, a cessation of their civil hostilities and a promise of peace. 35 Virgil's poem concerns the new golden age that has begun, under Pollio, with an unidentified newborn boy. I quote Virgil's poem from C. Day Lewis's clear and elegant translation, written in English hexameters, though in a stylistic register somewhat lower than Virgil's: ${ }^{36}$

Ours is the crowning era foretold in prophecy:

Born of Time, a great new cycle of centuries [novus ordo saeclorum]

Begins. Justice returns to earth, the Golden Age

Returns, and its first-born [or "a new generation"] comes down from heaven above.

Look kindly, chaste Lucina, upon this infant's birth, For with him shall hearts of iron cease, and hearts of gold Inherit the whole earth - yes, Apollo reigns now. (4-IO)

Isaiah's peaceable kingdom is unwittingly echoed: "the ox will have no fear of the lion"; "snakes will die" (22-24).

The "Justice" that returns to earth in Lewis's version is the goddess Astraea, the last of the immortals to leave the earth, referred to in Virgil as Virgo (later fueling Christian readings of the poem). In Greek tradition the last goddess on earth was Elpis, but by the time of the Caesars she had become Justice: in Ovid's account of the four ages in Metamorphoses, Book I, virgo ... / ultima caelestum terras Astraea reliquit (I49-50): "last of the deities, the virgin Astraea quit the earth." 37 Lewis's translation suggests a Virgin birth for the child of the poem ("its first-born"), but there is no clear warrant for doing so; the Latin nova progenies can mean either a "new child" 
or "new generation." It is only in turning to Lucina, the goddess of childbirth, that the poem clearly singles out one puero, or baby boy, who will give rise to gens aurea, a golden people and the personification of a new golden age. Historically, there are candidates for who this boy may be - an imagined child of Pollio, or Octavian and Scribonia, or Mark Antony and Octavia - but clearly the child has mythical, divine origins and powers. It is the child of justice and hope, as well as the conditions established by Pollio's consulship.

The child will go through stages of life, first in a nature purged of danger (no snakes or carnivorousness), and then, for a while, back into the world of warfare-but only, it seems, through books. "When you are old enough to read about famous men / And your father's deeds," then nature will be like early summer in farmland, ripening and reddening. But before the child reaches full adulthood, and nature recurs to its golden age, war recurs once more - but only in a past the child learns through martial poems (lines $3 \mathrm{I}-36$ ). Bruce Arnold notes that the boy's reading includes the Iliad and Catullus 64, a poem on the marriage of Peleus and Thetis, and the foretold birth of Achilles, set in Hesiod's gilded age of heroes. Both Catullus and Hesiod, Arnold shows, are intertextually engaged in Virgil's sophisticated poem..$^{8}$

After the child's term of literary warfare, perfect peace will ensue. But the poet gently ironizes his Isaiah-like vision:

Later, when the years have confirmed you in full manhood, Traders will retire from the sea, from the pine-built vessels They used for commerce: every land will be self-supporting [omnis ferret omnia tellus]. 
The soil will need no harrowing, the vine no pruning-knife; And the tough plowman may at last unyoke his oxen.

We shall stop treating wool with artificial dyes,

For the ram himself in his pastures will change his fleece's colour,

Now to a charming purple, now to a saffron hue, And grazing lambs will dress themselves in coats of scarlet. $(37-45)$

As with Hesiod, at the end there will be no more ships - the "primal error" (vestigia fraudis) mentioned earlier in line 3I - because "all lands shall bear all things" (39). But a sticking point for many interpreters of the poem are the ram and lambs who change their fleeces, seemingly at will, into the luxury colors of scarlet, purple, and saffron. Negative commentary goes back at least to T. E. Page's I 898 verdict: "There is only a step from the sublime to the ridiculous and Virgil has here decidedly taken it." 39 What the lines display, however, is Virgil's archness. $\mathrm{He}$ is less than serious about this new golden age and its magical reconciliation of leisure and luxury, Italiansoil and foreign wares. The conceit also affords Virgil a witty play on Jason and the Argonauts' mythical quest for the golden fleece: here fleeces are of many colors, and a purely literary phenomenon. Virgil (like Shelley after him) is a skeptical poet of urbane apocalypse. There was ruler hope in Virgil's air, in the late republic and later the principate, and Virgil was not entirely of its party - his intensely elegiac epic would bear this out, along with his signature, untranslatable phrase, lacrimae rerum (Aeneid I:462, literally "tears of things," often interpreted "tears for passing things"). 
Hope was, in Virgil's day, a revived deity. Roman Spes, an eponymous goddess from circa the fifth century BCE, had her earliest temple erected by 477 BCE. A new temple was built in Rome during the First Punic War, circa 258 BCE and, having burnt down several times, was restored under Augustus and in $\mathrm{I} 7 \mathrm{CE}$ dedicated by Germanicus Caesar. The development of hope as a religious-political virtue - roughly equivalent to "public confidence," Mark Clark argues - counterpoints the abiding distrust of private hope (as delusive, malevolent) in Roman as in Greek literature. ${ }^{40}$ Spes, conceptually tied to victory (Victoria) and national welfare or salvation (Salus), was a virtue associated with particular, charismatic, often young leaders in the Republican and Triumviral periods, including Scipio Africanus and, of course, Octavian, later Augustus, Caesar.4 Octavian appears as a potential savior in Cicero's Philippics, where at 5.49 Cicero argues that "the hope of liberty has been placed in the youth and ... salvation has come from him" (in hoc spes libertatis posita est; ab hoc accepta iam salus). ${ }^{42}$

Virgil's great tribute to public hope comes not in the whimsical fourth Eclogue but rather in actions of young Ascanius in the Aeneid. Ascanius, son of the melancholic Aeneas, bears the hope of founding what will become Rome. He counters, with his sense of public mission, the despair of the Trojan women who, in Sicily, attempt to burn the Trojan ships and thus put an end to travels that seem hopeless. Hope in the Italian lineage of Ascanius - also called Iulus (Julius), thus spes heredis Iuli (Aeneid 4.274) - pays tribute to the Julian line from which Augustus claimed descent, and to the promise his rule arguably fulfilled. ${ }^{43}$ 
Virgil implicitly wishes as well for an orderly imperial succession, a desideratum of still greater concern to his younger contemporaries and recurrent for the next 400 years. Velleius Paterculus, in Historia Romana (29 CE), explicitly praises Augustus' adoption, in $4 \mathrm{CE}$, of Tiberius - after the untimely deaths of two preferred successors. "On that day there sprang up once more in parents a sure hope of children, in husbands of marriage, in masters of inheritance, and in all men the hope of safety, order, peace, and tranquility; indeed, it would have been hard to entertain larger hopes, or to have them more happily fulfilled." ${ }^{4}$ Velleius' rhetorical heights may shade into hyperbole, but they underscore a truly anxious hope, at least among propertied males, that lineal descent remain secure at the family, estate, and imperial levels. Hope in orderly succession is, in all senses, an anti-revolutionary hope. Spes Augusta, "the hope of Augustus," became a common coin legend starting during the reign of the emperor Claudius (4I-54 CE), reflecting hope in both the emperor and his imperial heir or heirs. ${ }^{45}$ Through the fourth century CE - that is, shortly before the fall of the Western Roman Empire - emperors were praised in accord with the ruler hopes once given voice by Virgil. Gratian (emperor, 367-383) was praised by Quintus Aurelius Symmachus, a proponent of the ancient Roman religion, as the savior foretold by Virgil's Eclogue; bronze coins of Gratian with the inscription GLORIA NOVI SAECULI, "glory of the new age," allude to Virgil's prophecy that the great order of the ages (magnus ordo saeclorum) shall begin anew. ${ }^{6}$

In fact, Emperor Theodosius' death in 395 marked the end of effective administrative rule in the Western 
Empire. Rather than the golden age, Hesiod's second age of iron arrived - along with the barbarian Odoacer, likely of German descent. The irony is as terrible as that which condemned Thucydides' hopeful Melians to mass destruction. But viewed from a different angle, the Romans had been liberated from the hope against which they sometimes inveighed. The historian Tacitus, in Germania ( $98 \mathrm{cE}$ ), expresses primitivist admiration for the barbarians north of the Danube. He saw in the Fenni tribe (ambiguously German or Sarmatian) a glimmer of a golden age, however wretched it might look to luxurious, enslaved Romans. The Fenni are simple, and thus secure. Though having nothing more than branch shelters,

[T] hey regard themselves happier than those who groan over the tilling of fields, sweat over house-building, or risk the fortunes of themselves and others due to hope or fear. Unafraid of either men or gods, they have reached the most difficult of states: that they do not even feel the need to pray for anything. ${ }^{47}$

Free from hope or fear, averse to labor and desiring no goods they do not possess, the Fenni are, in their pre-philosophical way, philosophers.

\section{Beyond Hope and Fear: The Philosophic Tradition}

After Aristotle, philosophy tends to disapprove of passionate attachments in general, including most personal hopes. Aristotle, by contrast, found a normative place in his philosophy for the passions. But it is not clear whether or not he counted hope among them. Aristotle's The Art of Rhetoric includes a list of the social passions that the deliberative and judicial orator must know how 
to manipulate, because passions modify judgments..$^{8}$ The passions that interest Aristotle are chiefly those appropriate to the competitive, confrontational world of Athenian polis and so prominently feature anger and revenge, fear and shame. ${ }^{49}$ While hope does not appear in Aristotle's list of passions, it does feature as a constituent part of other passions, notably anger and fear. Anger, with which Aristotle begins his survey of the passions, is "the impulse, accompanied by pain, for visible retaliation in response to visible disparagement," but the pain involved in anger is counter-balanced by the "pleasure based on the expectation [or hope, from Greek elpis] of achieving retaliation" (I378a, 6r).

Whether or not Aristotle thinks of hope as a distinct passion or not, he holds that anger grows sweet because what is hoped/expected is vividly imagined: "as people linger in their minds over the prospect of retaliation, the images that occur arouse pleasure, just as images do in a dream" (I378a, 6I-62). Indeed, for Aristotle hope may be less of a passion than a mental state akin to dreaming: according to Diogenes Laertius (Lives of Eminent Philosophers 5.I7), Aristotle defined elpis as "a waking dream." However, elsewhere in Aristotle hope seems less a spectacle or narcotic than a judgment and incitement to action, specifically as it operates in fear. Suffering with regard to a fearful future is offset by hope in resistant activity: "fear makes people turn to deliberation [and thus rhetoric], and no one deliberates about a hopeless situation." Fear, then, in most contexts, generates hopeful calculations which may rise to the "confidence" (tharraleos) that Aristotle identifies as a passion, wherein "the hope of deliverance from danger is accompanied by an image 
in which the deliverance is close at hand" (I383a, 73). Confidence, which might also be translated as "audacity," is probably not a good thing.

Unlike Aristotle, the Stoics would clearly consider hope a passion, and they disapproved of passions. They were not alone in doing so. The Hellenistic schools of philosophy that arose in the Greek-speaking Mediterranean world of the early third century всE - Skepticism, Epicureanism, and Stoicism - were arguably influenced by Indian philosophy through Alexander the Great's campaigns into Central Asia and the Indian subcontinent (330-325 BCE) with a military force that included the founder of the Skeptic school, Pyrrho of Elis (c. 360-270 BCE). Stoic ethics accord with Brahman and Buddhist ideas about the centrality of moral duty without regard to (non-evidential) consequences, so that we should neither hope for success nor fear failure. The Bhagavad Gìtā features Krishna's advice to Arjuna: “To action alone has thou a right and never at all to its fruit; let not the fruits of action be thy motive ... Fixed in yoga, do thy work ... abandoning attachment, with an even mind in success and failure; for evenness of mind is called yoga." $5^{\circ}$ The ideal is to be anapeksah, translated from the Sanksrit as "desireless" or "without expectation": "He who has no expectation is pure, skillful in action, unconcerned, and untroubled." ${ }^{5}$ A roughly equivalent term attributed to the Buddha is nirāsa (or nirāsa), which may be translated as "hopeless," "without expectation," or "want-less." The latter translation features in the Chalmers translation of the Sutta-Nipāta: the "want-less," having no lack and complete in themselves, include "those who nowise crave / a future term of life, / on earth or anywhere." $5^{2}$ 
Early Buddhism may have been a specific influence, although it is notoriously difficult either to date or to place the Buddha, or establish the tenets of his earliest followers. Siddhārtha Gautama is believed by most scholars to have been born in India (though the earliest reference to him by name, in Chinese, calls him "the Scythian sage"). Our earliest complete Buddhist text, the Pāli Canon, is from the first century все. Conceding these difficulties, Christopher Beckwith nonetheless argues for early Buddhist influence on Pyrrho's skepticism. Pyrrho's espousal of "no views," or suspending judgment about non-evident matters for the sake of ataraxia (freedom from disturbance), is unprecedented in Greek thought (not appearing in ancient Cynics or Cyrenaics) but appears to be an early Buddhist idea..$^{53}$

Before circling back to the Stoics, I follow the influence of Pyrrho on his younger contemporary Epicurus, 34I-270 B все. Epicurus studied Pyrrho's teachings along with those of the fifth-century BCE atomist philosopher, Democritus. Epicurus' many works are largely lost to us today, so Epicureanism is known chiefly through later authors, most famously (if least doctrinally) the first-century вСE Latin poet Lucretius. Epicurus' philosophical aim, like Pyrrho's, is the happy life characterized by ataraxia. Epicurus was a hedonist (from Greek hedonē, pleasure); that is, he believed that pleasure (not virtue) was the greatest good, the ultimate aim. But for him, pleasure is the absence of pain (aponia). Epicurus courts tranquility alongside a social commitment to small communities of friends, outside of family networks and public affairs. Epicurus is not, in the popular sense, a hedonist (or small e "epicurean"); unlike Ecclesiastes, he does not exhort us 
to eat, drink, and be merry. He draws no carpe diem license from the practical atheism he derived from Democritus: the cosmos that pertains to us consists simply of atoms and void, and after death we are reduced to and reshuffled as atoms. Rather, he maintained that people should behave ethically because vice burdens them with guilt and prevents them from attaining ataraxia. Virtuous behavior contributes to the final end of pain-free tranquility.

In Lucretius' didactic poem on Epicurean philosophy, the two things that ruin most lives are, first, the fear of death and posthumous pain (possibly deriving from eternal punishment, as in Hades); second, erotic love for fickle or unworthy objects of desire (the only such objects he allows). His central concern with human fears (timor and metus) does not flip to admit hopes for more life, except by implication - not fearing death means abandoning hopes for longer life. Similarly, Lucretius does not address hope as part of what's wrong with erotic love, but in the context of the Latin erotic poetry against which he wrote (chiefly Catullus), "spes is intrinsic as a concept to (the failed expectations of) erotic experience." 54

In death, Lucretius insists in Book 3 of De Rerum Natura (lines 830-I094), we have nothing to fear; death is nothing to us. Dying, we simply dissolve into our constituent atoms, which get reused in the universe. But such insistence serves to allay hopes (for more life) as well as fears (of death and pain after death). Lucretius evokes disgust at the overextended life, thereby conceding that more life is something we typically desire or for which, as this desire extends into the future, we hope. Lucretius offers several arguments against fearing the reaper, and one of them may be paraphrased: you've led your life, 
you're full from the banquet, don't hesitate to leave and make room for others. This argument, attributed by Lucretius to the voice of personified nature, is elaborated in John Dryden's verse translation. Dryden places metrical emphasis on the pointless, cloying repetition that awaits the one who stays around too long:

To please thee I [nature] have empti'd all my store,

I can invent, and can supply no more;

But run the round again, the round I ran before.

(Translation of the latter part of the third Book of Lucretius, $\left.13^{8-40}\right)^{55}$

This last alexandrine of Dryden's triplet is spun from Lucretius' spare phrase, eadem sunt omnia semper, "all things are always the same" (De Rerum Natura 3:945, my translation). Dryden animates immutability by turning it into cyclical change, a pattern of rounds or circuits. Here, Nature's speech enacts the repetition it describes - "run the round again, the round I ran before" - via insistent alliteration, chiasmus (run round II round ran) and polyptoton (run/ran). Dryden thus enhances, in English, Lucretius' point: don't hope for more life. Death, when it comes, is not only necessary but timely - and here the point is clearly rhetorical rather than factual.

Roman Stoics made the same arguments about death's timeliness and the need to meet it without fear or distress whenever it comes - whether it be one's own death, or that of loved ones. So, from the Handbook of the Romanera Greek Stoic Epictetus (c. 50-I3O CE), always the most quotable of Stoic sources:

What upsets people is not things themselves but their judgments about the things. For example, death is nothing 
dreadful (or else it would have appeared dreadful to Socrates), but instead the judgment about death that it is dreadful - that is what is dreadful.

In the case of everything attractive or useful that you are fond of, remember to say just what sort of thing it is, beginning with the least little things. If you are fond of a jug, say "I am fond of a jug!" For then when it is broken you will not be upset. If you kiss your child or your wife, say that you are kissing a human being; for when it dies you will not be upset..$^{6}$

Stoicism was and remains a developing tradition, not tied to its founder - in this case, Zeno of Citium (334-262 всE) - as closely as was Epicureanism or Pyrrhonism. Romanera writers softened the edges of the various philosophical schools they imported from Greece, bringing them into synthetic contact, or eclectic medley, with one another. Still, there are two signal differences between Stoicism and Epicureanism: first, for the Stoics, virtue, not pleasure, is the greatest and indeed the only good. Roman Stoicism's ethical emphasis is on duty or appropriate action (Greek kathekon, Latin officium), rendering "indifferent" all other circumstances outside one's control, including pleasure, health, reputation, longevity, or continued life, and even the unforeseeable consequences of virtuous action. Second, whereas Epicurean physics involve purposeless atoms and void, the Stoics grounded their ethics in a view of nature that is at once more deterministic - chains of causal necessity that render whatever happens inevitable - but also more optimistic: whatever happens is, when viewed from a God's-eye view, beneficial. All is causally necessary, and yet this causal necessity is somehow for the greater good. (Stoic philosophy later bequeathed this sense of providential purpose to Christian theology.) 
The Stoics were largely but not wholly opposed to hope, a mental attitude they may have been the first to treat as a passion or emotion, as we now typically do. For the Stoics, hope becomes interchangeable with desire. In general, the Stoics aimed for apathy, Greek apatheia, or the absence of passions or pathe, literally "sufferings" or "diseases" (compare "pathology"). But some affects, including hope, could be good ones, insofar as they are not incompatible with rational judgments about things: for example, that a jug may break, a loved one die.

In a Stoic tradition found in Cicero's Tusculan Disputations 4.6, and probably deriving from an earlier Greek Stoic source, ${ }^{57}$ three of the four main pathe - irrational desire, fear, and pleasure - have corresponding eupatheiai or good affects. These good affects, based on correct evaluations of the worth of their objects, are, respectively, rational wishing (boulèsis or Latin voluntatis), prudent caution, and rational joy or uplift (chara, Latin gaudium). Rational wishing is interchangeable with rational hoping. The Jewish philosopher Philo of Alexandria (c. $20 \mathrm{BCE}-5 \mathrm{O} \mathrm{CE}$ ), probably drawing upon now-lost Stoic sources, uses elpis or hope instead of the technical term boulesis to convey an anticipatory state linked to rational joy or chara: "Hope is a certain anticipation (propatheia, also translatable as 'pre-emotion'), a joy before joy (chara tis pro charas), being an expectation of good." Hope, itself a joy, appears here as an affective state, whether emotive or, in a technical sense, pre-emotive..$^{8}$

The study of Stoicism in relation to Eastern philosophies has taken off in recent years, though less within traditional scholarship than in the blogosphere (googling "Buddhism and Stoicism" produces a very long list of 
spirited, amateur essays) and popular academic writing. 59 But Stoicism is less ascetic than Indian philosophies focused on the renunciation of desire. For the Stoics, desire must be brought into accord with the criterion of reason. Stoicism, in some of its forms, may seem closer to the limitation of hopes or desires found in Confucianism. The aphorisms of Confucius (or Kongzi), believed to have lived in sixth-century всE China, find an echo in Roman Stoicism that admits limited hopes amidst social commitment. Amy Olberding writes of Confucius on hope: "While Confucius is no Stoic - that is, he does not dismiss prosaic goods as but 'matters of indifference' he does nonetheless tightly circumscribe what influence prosaic goods will have on motivation and in evaluating his life." The hopes that are unworthy of the junzi or exemplary person are "the hope of being acknowledged (Analects I.I6, I5.19), securing and preserving an official, status-conferring position (Analects 4.I4, I7.I5), impressing others (Analects 14.24), and avoiding poverty (Analects I5.32)." Nevertheless, as Olberding shows, Confucius himself hoped for esteem and was frustrated. She concludes that he was an exemplar "not because he is wholly liberated from ordinary cares, but because he ... manages them in an extraordinary way." Moreover, his greatest hopes were for others and their attainment of a good life. ${ }^{62}$

If Confucius resembles any one Stoic, it is Seneca (c. 4 BCE-65 CE), in his commitment to social duties, humanization of the philosopher's creed, and love of aphorism. He writes in one of his essay-letters or Epistulae Morales to the civil servant Lucilius: "no one can have a happy life if he looks only to himself, turning everything to his own advantage. If you want to live 
for yourself, you must live for another." ${ }^{3}$ Fortune shone on Seneca during much of his life. Unlike Confucius, he enjoyed for a long time, as tutor and then advisor to the emperor Nero, all the amenities no philosopher could rightly hope for but might still sometimes enjoy: acknowledgment, high station, immense wealth. When fortune's wheel turned, and Seneca was implicated in a conspiracy against the emperor's life, he ended his own with compelled but nonetheless Stoic suicide. His seventy-seventh letter to Lucilius is a spirited defense of taking one's own life as and when appropriate: "life is never cut short as long as one lives honorably. It is complete no matter where you end it, as long as you end it in a good way" (77:4).

Seneca, we have seen, quoted to Lucilius a proverb against hope from the Greek Stoic Hecaton of Rhodes (fl. c. IOO BCE): "You will cease to fear, if you cease to hope" (Letter $5: 7$ ). Yet later, expanding on improper hopes to Lucilius, he implies proper ones. These are hopes for the happiness of others. Seneca hopes for another that his happiness will reside within him:

Anyone who is enticed by hope is anxious and unsure of himself, even if hope is for something close at hand or not difficult to get, even if the things one hoped for never prove disappointing. Do this above all, dear Lucilius: learn how to experience joy. Do you now suppose that because I am removing from you the things of fortune and think you should steer clear of hopes, those sweetest of beguilements, I am taking away many pleasures? Not at all: what I want is that gladness should never be absent from you. I want it to be born in your own home - and that is what will happen if it comes to be inside of you. (Letter 23:2-3) 
Seneca hopes for Lucilius' joy in the present moment, which he'll have if he doesn't project into the future or place his happiness in any object external to his own virtuous character or conduct. The only secure joy is in his self as an inner possession. But Seneca does not here practice what he preaches. Lucilius' happiness is external to Seneca's conduct or character; thus, Seneca is wishing for a state external to him, the happiness of another.

Overall, Seneca seeks emotional independence less than he does the improvement and security of others. He includes "the safety of one's homeland" as a primary good (Letter 66:5). And he is concerned for his wife Paulina (Letter I04). Writing of a fever he has had, in the ripe old age of his mid-sixties, he speaks (not without a dash of self-dramatization) of hoping to continue living not for his own but rather for Paulina's sake:

She is very anxious about my health. In fact, realizing that her soul is completely bound up with mine, I am beginning, in my concern for her, to be concerned about myself ... One has to give in, you see, to honorable feelings [honestis adfectibus]. There are times when, to honor a family member, one has to summon back one's dying breath, however painfully, and actually hold it in one's mouth. A good man should live not as long as it pleases him but as long as he ought to. (IO4:2-3)

Thus, desires and hopes that involve others - social emotions - are an acceptable burden to the Stoic. ${ }^{64}$ They qualify, in Cicero's terms, as good affects.

The good of home and the homeland tend to be the horizon of expectation in Seneca's letters to Lucilius, and also in the philosophically oriented poetry of Seneca's contemporaries and successors. In the Stoic-homiletic 
poems of Persius, hope for patria is offset by satire of present mores. His second Satire distinguishes between the proper object of prayer - "a heart rightly attuned towards God and man" - and the improper objects of his compatriots, prominently including hope for inherited wealth. ${ }^{65}$ Following Persius, Juvenal, a far more lashing satirist, complains at the outset of his tenth Satire (in Dryden's translation), "How void of Reason are our Hopes and Fears!"66 Juvenal concludes that the only proper object of prayer, if one must pray at all, is for mens sana in corpore sano (356), and the laborious virtues that foster tranquility. Fortune's seeming divinity derives from those who pray for her illusory goods, and thus the foolishly hopeful damn themselves. ${ }^{67}$ Juvenal's ideal is Stoic indifference to that which lies outside his control, coupled with an ideal of old, agrarian Roman hardiness, which he depicts as the once-and-future soil of virtue. While social duties may seem at first glance to be slighted, the Herculean toils he prefers to ease (360-62) must be for something, and the good of the homeland - its feeding, its defense - seems the implied, proper object of exertion.

None of the Roman authors I have touched upon expresses much faith in the overall goodness of the cosmos, a tenet of earlier Stoicism that recedes in its Latin reformulation. Seneca's contemporary, Lucan - also a Stoic (if not a crypto-nihilist) ${ }^{68}$ - and his second century CE Stoic successor, the emperor Marcus Aurelius, expressed doubts as to whether or not there is providential order to the universe. Were the Stoics right, or does the truth lie with the purposeless atoms and void of the Epicureans? In either event, Lucan urged liceat sperare timenti - "let the fearful have hope" (De Bello Civili 
[Pharsalia] 2.15). On the one hand, fear can be offset by hope in the divine will (the hope, later, of St. Augustine when he quotes Lucan's line in his Enchiridion on Faith, Hope, and Love). ${ }^{69}$ On the other hand, the fearful should take comfort in the good that might, by chance, come their way. Echoing these balanced possibilities of providence and chance in Pharsalia 2:7-15, Marcus Aurelius concludes that there is no reason to fear death in either an ordered or a disorderly universe:

[The world is] Either a hotchpotch, entanglement, and dispersal, or unity, order, and providence. In the former case, why do I wish to spend time in such a random assemblage and chaos? Why should I care about anything other than how one day I shall 'return to the earth'? But why should that disturb me? Dispersal will happen to me whatever I do. But in the latter case, I revere the directing power, stand firm, and have confidence in it..$^{\circ}$

Lucan encourages hope whether there is order or not. Marcus Aurelius leans toward a hope-based faith in the divine will and its goodness. With these two Latin writers we have come to the threshold of the Christian era. 